\title{
INFLUENCE OF NOMAD'S RELIGION ON PUPILS' ENROLMENT AND RETENTION IN NOMADIC SCHOOLS IN NORTH- CENTRAL GEOPOLITICAL ZONE, NIGERIA
}

\author{
M. A. JIBRIN., U. V. OYINVWI \& B. S. ABDULLAHI \\ Department of Educational Foundations \\ Faculty of Education \\ Nasarawa State University Keffi \\ Nasarawa State, Nigeria
}

https://doi.org/10.37602/IJSSMR.2020.3306

\begin{abstract}
The pastoral nomads tend to have the erroneous belief that the nature of the physical environment is suitable only for grazing purpose and not for any educational activities. This is capable of influencing their attitude towards any educational programme unless adequate measures are taken to change their attitude in one way or the other. The study examined the Influence of Nomad's Religion on Pupils' Enrolment and Retention in Nomadic Schools in North- Central, Nigeria. The study was guided by two objectives, two research questions and two null hypotheses. The objectives are to determine the influence of Nomad's Religion on enrolment of pupils in nomadic schools in North- Central Nigeria, examine the influence of Nomad's Religion on retention of pupils in nomadic schools in North- Central Nigeria. The study adopted a descriptive survey research design and the population of the study was 42 , 845 consisting of 17, 498 nomadic parents and 25, 347 nomadic children. A multi-stage sampling technique was used in selecting 120 nomadic parents and 261 nomadic school pupils. Two instruments were used in collecting data for the study, which were the proforma and a questionnaire. Descriptive statistics of mean and standard deviations were used to answer the research questions while Chi-square statistics were used in testing the null hypotheses. The findings of the study revealed a significant influence of Nomad's religion on the enrolment of pupils in nomadic schools in North- Central, Nigeria. The findings also revealed a significant influence of Nomad's Religion on retention of pupils in nomadic schools in North- Central Nigeria. The study concluded that nomad's religion has a significant influence on the enrolment and retention of pupils in Nomadic schools. It was however recommended that the curriculum planners of nomadic education should always take cognizance of nomad's religious beliefs in planning the curriculum.
\end{abstract}

Keywords: Nomad's religion, Enrolment, Retention, North- Central

\subsection{INTRODUCTION}

Educating pastoral nomads is confronted with many challenges due to their conservative attitude. One of the contentious issues in the pastoral nomadic education programme in Nigeria is how to change their attitude towards nomadic education in order to encourage their participation and thus benefit from the programme. For instance, Adriansen and Nielsen 


\section{International Journal of Social Sciences and Management Review}

(2012) argued that "the Fulani use their children for different roles in the maintenance of herds, thereby depriving them of pursuing education". They further pointed out that children start herding at age of five. This herding responsibility to children, therefore, has some repercussion on their participation in nomadic education. Obviously, the consequence of this situation could be devastating. These children will not have the opportunity to participate in the nomadic education programme. It is, therefore, worth noting that as a result, mass illiteracy has now become an endemic symbol of underdevelopment; a disease which is intractable and a phenomenon much prevalent in developing or non-industrialized countries of the world"

Nomads' religion plays a significant role in nomadic children's enrolment and retention. Enrolment and retention of nomadic children in primary showed that the enrolment rate of the children is always lower significantly. In the same vein, the rate of retention also follows the same pattern. This ugly scenario calls for serious concern. Many factors have been attributed to this negative trend. Cultural beliefs and religious beliefs besides the widespread poverty level of most parents and guardians may be responsible for this condition. It has been an oldtime belief that the nomadic children should not be enrolled in school, but should be carried out and graze cattle. Some nomadic religious beliefs also frown at enrolling the children in especially in western school education. In the same vein retention of the nomadic children in primary schools has been on the decline over the years.

As a result of the aforementioned problems, many nomads became adamant in their opinion to prefer keeping their children to rearing animals than sending them to schools to acquire western education. Fortunately, the few ones that attended and completed schools among the nomads were successful. These successful nomads today are considered as the leaders who represent the nomadic community in national and international issues. Hence, this study examined the influence of nomad's religion on the enrolment and retention of pupils in nomadic schools in North Central Geo-political zone of Nigeria.

\subsection{Statement of the Problem}

The nomadic parents are locked into their own traditions and were stubbornly opposed to any change or push for innovation. At best, they are seen as very conservative and slow to embrace the new national society, in historical settings in which "the rest of the country cannot wait for them to develop". One of the manifesting ways to resist change is to reject education, such a rejection is understood as ultimately based on beliefs and ignorance: "people do not know the value of education". Pastoralists' attitude towards school is described as irrational against their own interest. They do not see the importance of being 'enlightened', pulled out of their primitive darkness and into the modern world (Bernard, 2015).

It is, however, important to note that the religious belief of the home where a pupil emanates may go a long way in determining his/her enrolment and retention in the course of learning. While some pupils may receive the required support and motivation from parents, others may not be fortunate to receive much from their parents. Furthermore, the incessant movement of some nomadic parents in the course of their cattle business may also influence school enrolment and pupils' retention. If school enrolment and pupils' retention is to improve in 


\section{International Journal of Social Sciences and Management Review}

Volume: 03, Issue: 03 “May - June 2020”

ISSN 2582-0176

North-Central, then the influence of religion cannot be overruled. The main thrust or focus of this study, therefore, is to examine the influence of nomad's religion on enrolment and retention of pupils in nomadic schools in Northcentral Nigeria.

\subsection{Aim and Objectives of the Study}

The aim of the study was to determine the Influence of Nomad's Religion on Pupils' Enrolment and Retention in Nomadic Schools in North Central Geopolitical Zone, Nigeria. The specific objectives are to;

1. Examine if there is any influence of nomad's religion on pupils' enrolment in nomadic Schools in North Central Nigeria.

2. Determine if there is any influence of nomad's religion on pupils' retention in nomadic schools in North Central Nigeria.

\subsection{Research Questions}

Based on the aim and objectives of the study, the study answered the following research questions:

1. Is there any influence on nomad's religion on pupils' enrolment in nomadic schools in North Central Nigeria?

2. Is there any influence on nomad's religion on pupils' retention in nomadic schools in North Central Nigeria?

\subsection{Research Hypotheses}

The following hypotheses were tested at 0.05 level of significance:

Ho1: There is no significant influence of nomad's religion on the enrolment of pupils in a nomadic school in North-central Nigeria.

Ho2: There is no significant influence of nomad's religion on retention of pupils in a nomadic school in North-central Nigeria.

\subsection{LITERATURE REVIEW}

\subsection{Nomad's Religious Beliefs and Nomadic Education in Nigeria}

Ezeoma (2010) reported that most of the pastoral nomads who were asked about their religion answered they were Muslims. This means that exposure to some kind of education is not new to them. Quranic Mallams have several decades been following the nomads from one ruga to another teaching them the message of the Quran (Ezeoma et al, 2010). Vereck (2012) noted that they may refuse to attend nomadic education because they feel that is a Christian type of education that will interfere with their religion. There could be the possibility that nomadic education will not uphold Islamic religion and so it will lead them to abandon their Islamic way of life. 


\section{International Journal of Social Sciences and Management Review}

In his own argument, Edet (2015) noted that Nomadic Fulanis feel that sending their children to Nomadic schools will tamper with their Islamic moral standards. That such an education provision will corrupt their children and turn them away from being obedient and from giving adequate attention to their cows. In a general outlook, the Nomads see nomadic education as standing against their religion and given this, they will not want to get involved.

Ardo (2016) observed that this is an unfavourable attitude in the pastoral Fulanis towards Nomadic education perhaps owing to their belief that such educational provision will erode their religious practices. They see Nomadic education as unnecessary to them, Islamic education is enough to keep them going economically and spiritually. Tampering with their already established beliefs is equal to failing in their obligations towards God. Be this as it may, they see Nomadic Education which has an infusion of western culture as a tool to weaken their Islamic beliefs.

In a similar observation, Lar (2012) cautioned that if the Nomadic education programme does not take care of the economic activity of the recipients and of course their religious belief, it may be difficult to sustain their interest and zeal to learn successfully to the end. He argued that any attempts to make the Nomads Education as a deviation from their religious inclinations will definitely dampen their interest in the activity no matter how censored and organized.

\subsection{Nomads Religion and Children's Enrolment and Retention}

Enrolment and retention of nomadic children in primary showed that the enrolment rate of the children always lowers significantly. In the same vein, the rate of retention also follows the same pattern. This ugly scenario calls for serious concern. Many factors have been attributed to this negative trend. Cultural beliefs and religious beliefs besides the widespread poverty level of most parents and guardians are responsible for this condition. It has been an old-time belief that the nomadic children should not be enrolled in school, but should be carried out and graze cattle. Some nomadic religious beliefs also frown at enrolling the children in especially in western school education. In the same vein retention of the nomadic children in primary schools has been on the decline over the years.

Another cultural factor is the ethnic group which is the highest echelon and the conflation of the kinship groups. It embodies all members with a common origin, sharing a founding ancestor whose personage may or may not be known, or whose genealogical link may not be traced to individual members. The clan is the sub-unit of the tribe, which anthropologists defined as the "collective descendants of a vaguely known historical ancestor" The clan members, by tradition, share mythical historical ancestry. Each clan consists of about a thousand to five thousand members. Genealogical ties among clan members are obscure. A clan consists of several lineage groups, although in language and territory, the distinction between the clan and the lineage is blurred. The members of a lineage, that is, descendants of a more recent male ancestor, have mutual obligations during attack, defence, or vengeance (Shanmugaratman, Vedeld, Mossigeand Bovin, 1992; Bonfiglioli 1993). The lineage members, who have closer historical ancestry than the clan members, comprise five hundred to one thousand members. The family is a branch of the lineage group and is the basic social as well as the smallest political unit organized around a patrilineal homestead. Made up of 


\section{International Journal of Social Sciences and Management Review}

five to fifteen members, the agnatic family is created by marriages and births (Bonfiglioli 1993).

Within the families are compartments or household that eat at least one meal a day together, the Ruga or homestead is the domestic unit, consisting of a man, his wife or wives, unmarried children, and dependant parents. Each household represents a cattle-owning entity, headed by the eldest, most able-bodied member of the family. To summarize, the Fulani are endogamous as well as polygamous. The Fulani are governed by a political structure consisting of the ethnic group, the clan, the lineage, the family, and the Ruga. Leadership among the Fulani is less aristocratic. A family is a herd-owning unit, united by common territory and occupation. Their herding system, described in the section that follows, involves frequent pastoral movement.

\subsection{RESEARCH METHODOLOGY}

\subsection{Research Design}

The descriptive survey research design was employed for this study. Afolabi (2013) and Osuala (2012) recommended that a descriptive survey research design was ideal when collecting data that was used to ascertain the impact of one variable on another. They also remarked that this method unveils data, interprets, synthesizes and integrates and interprets the data appropriately.

\subsection{The population of the Study}

The target population of the study was 42,845 consisting of 17, 498 nomadic parents and 25 , 347 nomadic school children. The population of pupils was obtained from the records of the State Nomadic Commission in Nasarawa, Plateau, Niger, Kogi, Benue, the Kwara States and the Federal Capital Territory, Abuja. Also, the population of the parents is obtained from the National Population Commission (2006).

Table 1: Distribution of Population of the Study

\begin{tabular}{rlrrrrr}
\hline SN & State & $\begin{array}{l}\text { Number } \\
\text { Nomadic } \\
\text { Schools }\end{array}$ & $\begin{array}{l}\text { Population } \\
\text { Parents }\end{array}$ & $\begin{array}{l}\text { Population } \\
\text { pupils }\end{array}$ & $\begin{array}{r}\text { of } \\
\text { Total Number } \\
\text { of Respondents }\end{array}$ \\
\hline 1 & Nasarawa & 76 & 3125 & 4934 & 8059 \\
2 & Plateau & 92 & Not Monitored & Not Monitored & Not Monitored \\
3 & Niger & 210 & 2566 & 3112 & 5678 \\
4 & Kogi & 9 & 1987 & 2514 & 4501 \\
5 & Benue & 23 & 2041 & 3385 & 5426 \\
\hline
\end{tabular}




\section{International Journal of Social Sciences and Management Review}

Volume: 03, Issue: 03 “May - June 2020”

ISSN 2582-0176

$\begin{array}{llcccc}6 & \text { Kwara } & 89 & 3314 & 4719 & 8033 \\ 7 & \text { FCT, Abuja } & 44 & 4465 & 6683 & 11,148 \\ & \text { Total } & \mathbf{5 4 3} & \mathbf{1 7 , 4 9 8} & \mathbf{2 5 , 3 4 7} & \mathbf{4 2 8 4 5}\end{array}$

Source: National Population Commission 2006, States Nomadic Commission 2018.

\subsection{Sample and Sampling Technique}

A sample size of 381 subjects was selected for this study (120 parents and 261 pupils) as recommended by Paul (2006) in the table of determining sample size for research activities. A multi-stage sampling technique was used in selecting the sample for the study. In the first stage, four states were purposively selected out of the 7 states in the North-central zone, based on the high number of pupils' enrolment. The selected states are Nasarawa, Benue, the Kwara States and the Federal Capital Territory, Abuja. In the second stage, purposive sampling technique was equally used in selecting 3 schools each from the four selected States. In the final stage, a simple random sampling technique was used to select participating nomadic Parents in their cluster and school children in every school visited. In selecting the pupils, the researcher gathered all the pupils and write "Yes" on pieces of papers for the required number and "No" for the remaining number. These were folded and put in a container, shuffled well and pupils were asked to dip hand and pick one after the other. Those that picked "Yes" were considered for the study while those that picked 'No' was appreciated and kindly informed that they would not participate in the study.

The sample size was therefore comprised of 120 nomadic parents and 261 nomadic school children in the selected states.

Table 2: Distribution of Sample for the Study

\begin{tabular}{|c|c|c|c|c|c|c|}
\hline SN & State & Sample Schools & $\begin{array}{c}\text { Population } \\
\text { of Parent }\end{array}$ & $\begin{array}{l}\text { Sampled } \\
\text { Parents }\end{array}$ & $\begin{array}{c}\text { Population of } \\
\text { Pupils }\end{array}$ & $\begin{array}{c}\text { sampled } \\
\text { pupils }\end{array}$ \\
\hline 1 & Nasarawa & $\begin{array}{l}\text { Jere } \\
\text { YakubuAgyaragu } \\
\text { Dauri }\end{array}$ & $\begin{array}{l}412 \\
266 \\
187\end{array}$ & $\begin{array}{c}12 \\
8 \\
6\end{array}$ & $\begin{array}{l}452 \\
295 \\
228\end{array}$ & $\begin{array}{l}25 \\
17 \\
13\end{array}$ \\
\hline 2 & Benue & $\begin{array}{l}\text { Mbaikye } \\
\text { Mkomon- Waya } \\
\text { Abinsi }\end{array}$ & $\begin{array}{l}453 \\
191 \\
175\end{array}$ & $\begin{array}{c}13 \\
6 \\
5\end{array}$ & $\begin{array}{l}480 \\
221 \\
202\end{array}$ & $\begin{array}{l}27 \\
12 \\
11\end{array}$ \\
\hline 3 & Kwara & $\begin{array}{l}\text { GaaDawo } \\
\text { Igbo- Irese } \\
\text { GaaGaladima }\end{array}$ & $\begin{array}{l}168 \\
123 \\
108\end{array}$ & $\begin{array}{l}5 \\
4 \\
3\end{array}$ & $\begin{array}{l}210 \\
147 \\
138\end{array}$ & $\begin{array}{c}12 \\
8 \\
8\end{array}$ \\
\hline 4 & $\begin{array}{l}\text { FCT, } \\
\text { Abuja }\end{array}$ & $\begin{array}{l}\text { Dakwa } \\
\text { Tudun Fulani }\end{array}$ & $\begin{array}{l}974 \\
589\end{array}$ & $\begin{array}{l}29 \\
18\end{array}$ & $\begin{array}{c}1256 \\
622\end{array}$ & $\begin{array}{l}70 \\
35\end{array}$ \\
\hline
\end{tabular}




\section{International Journal of Social Sciences and Management Review}

Volume: 03, Issue: 03 "May - June 2020"

ISSN 2582-0176

$\begin{array}{lllll}\text { City Gate } & 381 & 11 & 409 & 23\end{array}$

Total

4027

120

4660

\subsection{Methods of Data Collection}

Two instruments were used for this study which was the proforma and the questionnaire developed by the researcher titled" Questionnaire on the Influence of Nomad's Religion on Enrolment and Retention of pupils in Nomadic Schools (QINRERPINS)' which contained 50 items. The instrument was designed on 5- point Likert scale of Strongly Agree, Agree, Undecided, Disagree, and Strongly Disagree. The weighted mean of 3.0 and above was used as a benchmark for decision.

\subsection{Administration of the Instrument}

The instrument was administered using face to face delivery method by the researcher and 4 research assistants with prior arrangement with the concerned nomadic schools and parents. The researcher with the help of 4 research assistants followed the nomadic parents in their respective locations where the contents of the instrument was translated to the Hausa language for those that cannot read and write to determine their attitude towards nomadic education under Universal Basic Education. With the aid of the instructors of the sampled nomadic schools, the consent of the pupils, the privacy of information, other ethical sureties was guaranteed to the pupils.

\subsection{Technique for Data Analysis}

Descriptive statistics of Mean and standard deviations were used to answer the research questions framed for the study. The hypotheses were however tested at 0.05 level of significance using chi-square obtained from SPSS version of 50.

In answering the research questions any weighted mean below 3.0 was considered to disagree while above was considered agree. In testing the hypotheses formulated, the p-values (probability values) of F-cal served as the basis for acceptance or rejection of hypothesis being tested. Hypotheses whose p-values were found to be less than 0.05 , they were rejected while for those greater than 0.05 they were retained.

\subsection{RESULTS AND DISCUSSION}

\section{Answers to Research Questions}

Research Question One: How does nomad's religion influence pupils' enrolment in nomadic schools in North Central Nigeria?

Table 3: Mean and Standard Deviation on the Influence of religion on the enrolment of pupils in nomadic schools in North Central Nigeria 


\section{International Journal of Social Sciences and Management Review}

Volume: 03, Issue: 03 “May - June 2020"

ISSN 2582-0176

\begin{tabular}{|c|c|c|c|c|c|c|c|c|c|c|}
\hline $\mathbf{S} / \mathbf{N}$ & ITEMS & $\mathbf{N}$ & $\mathbf{S A}$ & $\mathbf{A}$ & $\mathbf{U N}$ & $\mathbf{D}$ & SD & $\overline{\overline{\mathbf{X}}}$ & SD & Remark \\
\hline 1. & $\begin{array}{l}\text { Fear of religious belief } \\
\text { prevent me from enrolling } \\
\text { my children in school. }\end{array}$ & 381 & 95 & 48 & 7 & 62 & 169 & 2.57 & 1.70 & Rejected \\
\hline 2. & $\begin{array}{ll}\text { The impression } & \text { that } \\
\text { nomadic education will } \\
\text { negatively affect our } \\
\text { religious code halt my } \\
\text { children's enrollment in } \\
\text { school. }\end{array}$ & 381 & 115 & 50 & 6 & 62 & 148 & 2.80 & 1.73 & Rejected \\
\hline
\end{tabular}

3. Because nomadic education will expose my children $\begin{array}{lllllllll}381 & 68 & 116 & 0 & 66 & 131 & 2.80 & 1.59 & \text { Rejected }\end{array}$ against our religious I refuse to enroll them in school

4. The element of western $\begin{array}{llllllllll}381 & 35 & 85 & 3 & 70 & 188 & 2.24 & 1.47 & \text { Rejected }\end{array}$ education that is incorporated into nomadic education will negatively influence the life of my children as such they are not enrolled in school

5. The fear that my children $\begin{array}{lllllllll}381 & 82 & 104 & 0 & 81 & 114 & 2.89 & 1.59 & \text { Rejected }\end{array}$ will embrace western education at the expense of nomadic made me not to enroll them in school

Grand Mean

Table 3 shows how nomads' religion influences the enrollment of pupils in nomadic schools in North Central, Nigeria. The result from the study revealed that none of the items is above the criterion mean of 3.00 used as a benchmark. The obtained result further implies that the respondents disagreed that nomads' religion has an influence on pupil's enrollment in nomadic schools in North Central Nigeria.

Research Questions Two: How does nomad's religion influence pupils' retention in nomadic schools in North Central Nigeria?

Table 4: Mean and Standard Deviation on the Influence of religion on the retention of pupils in nomadic schools in North Central Nigeria

\begin{tabular}{lllllllllll}
\hline S/N & ITEMS & N & SA & A & UN & D & SD & $\overline{\mathbf{X}}$ & SD & Remark
\end{tabular}




\title{
International Journal of Social Sciences and Management Review
}

Volume: 03, Issue: 03 “May - June 2020”

ISSN 2582-0176

1. My children could not be retained in school because of religious belief.

2. When I see the nomadic school dress code I remove my children from school because it will affect their religious belief.

3. I could not retain my children in school because it is glaring that will be exposed to abuse my religion.

4. I decided to take my children $\begin{array}{lllllllll}381 & 46 & 85 & 28 & 38 & 184 & 2.40 & 1.54 & \text { Rejected }\end{array}$ out of school because they are being negatively influenced by the teaching of Christian religion.

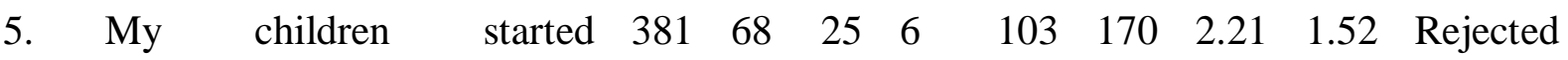
embracing Christianity religion against nomadic that is why I refused to allowed them to continue with western education.

\author{
$\begin{array}{lllllllll}381 & 45 & 86 & 0 & 80 & 170 & 2.36 & 1.51 & \text { Rejected }\end{array}$
} $\begin{array}{lllllllll}381 & 72 & 58 & 3 & 62 & 186 & 2.39 & 1.63 & \text { Rejected }\end{array}$

$\begin{array}{lllllllll}381 & 88 & 56 & 8 & 63 & 166 & 2.57 & 1.67 & \text { Rejected }\end{array}$ Grand Mean

Table 4 shows how nomads' religion influences the retention of pupils in nomadic schools in North Central, Nigeria. The result revealed that none of the items is above the criterion mean of 3.00 used as a benchmark. With a mean of 2.57, respondents disagree that exposure to religious practices and belief cannot make them retain their children. Findings from the result imply that the respondents disagreed that nomads' religion has influences pupil's retention in nomadic schools in North Central Nigeria.

\section{Hypotheses Testing}

HO1: There is no significant influence of nomad's religion on the enrolment of pupils in a nomadic school in North-central Nigeria.

Table 5: Chi-square test statistics on the Influence of nomad's religion on the Enrolment of pupils in a nomadic school in North-central Nigeria 


\section{International Journal of Social Sciences and Management Review}

Volume: 03, Issue: 03 "May - June 2020"

ISSN 2582-0176

\begin{tabular}{ccccccc}
\hline Variables & Df & $\begin{array}{c}\text { Alpha } \\
(\boldsymbol{\alpha})\end{array}$ & $\chi^{2}$ cal & $\chi_{\text {tab }}^{2}$ & $\begin{array}{l}\text { p- } \\
\text { value }\end{array}$ & Decision \\
\hline Nomads' Religion*ENR & 380 & .05 & 46.43 & 26.3 & .030 & $\begin{array}{c}\text { Reject } \\
\mathrm{HO}_{5}\end{array}$ \\
\hline
\end{tabular}

Level of significance $\alpha<0.05$ significant Level; ENR = Enrolment

Table 5 shows the Chi-square statistics $\left(\chi^{2}\right)$ on the influence of nomads' religion on the enrollment of pupils in a nomadic school in North Central, Nigeria. The result revealed that there is a significant influence of nomads religion on the enrollment of pupils $\left[\chi^{2}(380)=\right.$ $46.43 ; \mathrm{p}<.05]$. Findings from the study imply that nomads' religion has a significant influence on the enrollment of pupils in a nomadic school in North Central, Nigeria. The formulated hypothesis was therefore rejected.

HO2: There is no significant influence of nomad's religion on retention of pupils in a nomadic school in North-central Nigeria.

Table 6: Chi-square test statistics on the Influence of nomad's religion on the Retention of pupils in a nomadic school in North-central Nigeria

\begin{tabular}{ccccccc}
\hline Variables & Df & $\begin{array}{c}\text { Alpha } \\
(\boldsymbol{\alpha})\end{array}$ & $\chi^{2}$ cal & $\chi_{\text {tab }}^{2}$ & $\begin{array}{l}\text { p- } \\
\text { value }\end{array}$ & Decision \\
\hline Nomads' Religion*RET & 380 & .05 & 93.87 & 26.3 & .012 & $\begin{array}{c}\text { Reject } \\
\mathrm{HO}_{6}\end{array}$ \\
\hline
\end{tabular}

\section{Level of significance $\alpha<0.05$ significant Level; RET $=$ Retention}

Table 6 shows the Chi-square statistics $\left(\chi^{2}\right)$ on the influence of nomads' religion on the retention of pupils in a nomadic school in North Central, Nigeria. The result revealed that there is a significant influence of nomads religion on the retention of pupils $[\chi 2(380)=$ $46.43 ; \mathrm{p}<.05]$. Findings from the study imply that nomads' religion has a significant influence on the retention of pupils in a nomadic school in North Central, Nigeria. The formulated hypothesis was therefore rejected.

\subsection{CONCLUSION}

Based on the findings of the study, it was concluded that Nomad's religious beliefs have negative effects on enrolment and retention of pupils in nomadic schools in North Central Geopolitical Zone of Nigeria. The study, therefore, recommended for the curriculum planners of nomadic schools to always take cognizance of the nomad's religious believes in planning the curriculum.

\section{REFERENCES}

Adriansen, H. K. \& Nielsen, T. T. (2002). Going Where the Grass is Greener: On the Study of Pastoral Mobility in Ferlo, Senegal. Human Ecology 30 (2): 215-226. 


\section{International Journal of Social Sciences and Management Review}

Volume: 03, Issue: 03 “May - June 2020”

ISSN 2582-0176

Afolabi, M. (2013).Introduction to Research for writing Proposal and thesis, Zaria: Alpha publishers.

Ardo, A.A.(2016). Education for pastoral nomads: the nomadic education programme in Nigeria, unpublished $\mathrm{PhD}$ thesis, the University of Manchester, UK.

Bernard, F. (2015) Technologies for Nomadic Education, Ibadan. University Press Ltd

Bonfiglioli, M. (1993).Agro-pastoralism in Chad as a Strategy for Survival: An Essay on the Relationship between Anthropology and Statistics. Washington, D.C.: World Bank Technical Paper No. 214.

Ezeoma C. (2012). Settlement Patterns of Nomadic People. Implication for Development. London : Dean House Ltd.

Lar, M. (2012).Studies in Nomadic Education: Implication for Curriculum and Instruction Jos: Ehimdero (Nig.) Ltd.

NPC, (2006). National Population Commission, available on www. Population.gov.ng/ Retrieved 7th September, 2016. Number 3-4 summer/Autumn.

Osuala, E.G. (2012).Principles and Methods of Business and Computer Education, Nsukka: Godjiksons Publishers, pp. 4-9.

Paul, C. B. (2006).Determining sample size for research activities; Educational and Psychological Measurement; 30, pp. 607-610). Copyright, 2006, The Research Advisors (http://research-advisors.com), All rights reserved.

Shanmugaratman, N., Vedeld, T., Mossige, A. \&Bovin. M. (1992).Resource Management and Pastoral Institution Building in the West African Sahel. Washington, D.C.: World BankDiscussion Paper No. 175.

Vereck, P. (2012). An Empowering Symbol Among the Pastoral Fulbe in Nigeria. In. G. Tahir (ed). Education and Pastoralism in Nigeria Zaria: A.B.U. Press Ltd. 